\title{
Between The Ethical Code and the Breach in Advertisement Media
}

\author{
Pujiyanto \\ Art and Design Department of Faculty of Letters of Malang State University INDONESIA
}

\begin{abstract}
Printed advertisement is the one presenting the verbal and visual message leading to the audience's response. Every advertisement has a certain market segment coverage corresponding to the assignment informed through the media intended to the audience. The presence of an advertisement is not only determined by the advertiser's creativity, but also affected by the existing rule. In the advertising studies related to ethical codes, the author limited to the Food and Drug Administration's rule, advertising etiquette and ethical code, and intellectual property right. Those three rules are frequently used in creating an advertisement media design. The sample of research was limited to the printed advertisement of "Madurasa" brand from PT. Air Mancur Solo. Through the advertisement media, this brand had ever achieved "Top Brand" award four times in 2009. 2012 period. To recognize the advertisement, the data was obtained from interview and document. These two data sources would be studied for its legislation application and breach. All of the data collected would be analyzed using Graeme Burton theory that the media is limited to law and control.
\end{abstract}

Keywords: Advertisement, media, printed advertisement, ethical code, breach.

\section{Introduction}

Advertisement is the media of delivering a product or service from the message sender (institution/producer) to the message receiver (public) having mass esthetic to make the public provoked, interested, excited in approving and following. In delivering the message indirectly, it is published through the media visible to the public, so that positive reaction and action will result.

Media is the message intermediary or deliverer from the message sender to the receiver. Overall, it is human being, material or event that builds a condition that enables the college students acquiring knowledge, skill, or attitude. In this definition, lecturer, textbook, and campus environment is a media (Arsyad, 2002). Media is any intermediary forms used as idea distributor, so that such the idea will arrive at the receiver. Media is a channel, because essentially it has expanded human being's ability to feel, to hear, and to see certain distance, spatial and temporal borders. Media is a medium used by the message sender, in which it is a way or a means by which a message runs between the communicator and the communicant (Rohani, 1997).

Media can enable us to build a moral solidarity relationship imaginatively. Media can be an instrument used independently and directly to establish a separated relationship in contrast to what we say or tend to believe. Basically, media serves as a moral enlightening vehicle, because there is an in-depth dialogical relationship between media text and its audience (Tester, 2009). Everyone believes that media indeed has a power. Graeme Burton (2008) stated that the main power of media lies in the fact that media can create what we know about the world and can be the main source of various ideas or opinions. Essentially, media can influence the way we think and act.

Bourdieu (1993) has another opinion about media, that economy is not merely an ideological mask or simple evasion from economic interest. On the one hand, the new producers only rely on the belief that they can establish themselves in the market by holding on the values used. The term ideology in media is intended to the public, according to Burton (2008) is defined as follows: (1) ideology refers to the ideas on the essence and the operation of power relationship as well as a variety of beliefs and values in the community culture. How does a variety of media aspects contribute to the sustainability of beliefs and values within the society? (2) Institution is the organizations running and controlling media. (3) Text, that all products (packages) are the media paying attention to the fact that can be read to find out the meanings. But, how the text can be read differently by the different audience. (4) Social context, there should be a public awareness of the news contextualized by social environment. (5) Audience, can be defined based on social grouping. To what extent does the audience's perception on social group influence the preference targeted to them. Media is restricted by law, by their relationship to the government, and by their voluntary control. The media institutions operate specifically through routine. They operate based on marketing strategies and market need, under the effect of professional ideas created by media (Burton, 2008).

Advertising media created in house by PT. Air Mancur is always affected by the market. The presence of advertisement media is intended to make the advertised product sold-out. As a company's marketing strategy, 
the advertisement media design is created well and attractively corresponding to the target market. Advertisement media cannot be apart from ethical code and etiquette but it should have market orientation. Graeme Burton states that media is restricted by law and control. Media operates routinely, created professionally by the market demand.

\section{Research Methods}

Advertisement is a media serving as message deliverer from sender (producer) to audience (consumer). Advertiser, as the creator of advertisement media, of course, has mass esthetics functioning as the communication means for advertising activity. Advertisement frequently appears in printed mass media as daily consumption. So many advertisements present sometimes are not consistent with the existing rule. In this research, the author selected several advertisements considered as representative, therefore the purposive sample was used corresponding to the objective of research. The data of research was collected using observation and document techniques.

The observation used here was an open, independent or non-participatory one, meaning that the author merely served as the observer. The naturally background (unstructured) observation is the one conducted in the real location in qualitative method. Observation was conducted directly over the advertisement media in printed mass media. Observation was conducted to find out the extent to which the advertisement media breaks the advertising ethical code and etiquette.

Document data was a secondary one. Document is the data obtained from book, advertisement work, and other archives, constituting the instruments to find out how much the "Madurasa" product advertisement media is used by PT. Air Mancur Indonesia. The data of document was obtained from either inside or outside the company. The document technique used included (a) formal document, constituting the one issued by institutions or companies, such as advertisement media design work, company's correspondences, government regulation in the form of ethical code, artifact, and other official regulations, and (b) informal document, the one merely constituting official record, such as the record of advertising media design stage phase.

In this research, data adaptation and integration were done as necessary, so were the analysis techniques. The analysis was conducted using Graeme Burton's theory stating that media is restricted by law and should take the professional ethical code into account. The data analysis consisted of three interrelated subprocesses: data reduction, data display, and conclusion drawing. (1) Data reduction was carried out when the field note and other data had been available. The next selection stage was data summarizing, grouping and written narrative presentation. (2) Data display is a densely structured information construction. This process allows the conclusion drawing and action implementation by studying the data reduction process to consider whether or not there is an ethical code breaking. The data display focused more on structured summary and synopsis. (3) Conclusion drawing and verification were carried out in interpreting process, in determining the application of ethical code in the presented data.

\section{Result}

Ethical code is a set of stipulations and regulations mutually agreed in order to govern the members of organization's conduct. Such the ethical code is an bond, a rule (order), or norm containing the instructions for the members of organization, about prohibitions, that is, what they may or may not do, not only in undertaking their profession, but sometimes also pertaining to their conduct within the society generally (http://www.scribd.com/Kode Etik Profesi).

Ethical code is the regulation designed by the government with several society profession institutions, for anything done by professional institutions or institution to be not pertaining to ethnic, religion, race, and custom (SARA) as well as accountable for. Wiryawan (2007), states that in the presence of ethical code, the company is expected thinking not merely of for-profit business, but also humanity values. If it is neglected, 'humanity' spirit will be contaminated by the company's private interest. In the presence of ethical code, it is expected that the advertisement media an individual or a group of society or an advertisement agency creates will not become the polemics within the society. The presence of rule is expected to prevent the negative competition from occurring between the publication and advertisement agencies, and the consumer from being harmed by the producer through advertisement media. The presence of rule is expected to make the advertisement media get public acceptance and not pertaining to SARA and respecting each other. In the presence of ethical code, in-house advertiser feels less independent in creating, therefore unconsciously they create too emotionally thereby break the preexisting rule.

\section{1) Several types of regulation}

There are several regulations affecting the presence of "Madurasa" advertisement media including: (a) Food and Drug Administration's rule, (b) Advertising Etiquette and Ethical Code, and (c) Intellectual Property Right. 
The presence of such the legislations are expected to make the advertising media delivering the message ethically and consistent with the rule.

\section{a) Food and Drug Administration's rule}

Food and Drug Administration (BPOM RI)'s rule is the one governing the procedure and the rule in designing the product packaging. For example, the Chairman of Food and Drug Administration's Decree Number HK.00/05.1.2569/2004 states that "the size of letter and number used on the label of product packaging should be sizable and may not be less than $1 \mathrm{~mm}$. Such the decree was corroborated by the Health Minister's decree number 368/MEN.KES/SK/IV/1994, about technical manual in creating a printed advertisement (packaging), explaining that: (1) the writing should be readable, (2) the type of letter should be capital, black and bold, (3) the minimal letter size should equal to that of body copy, and (4) should be bordered with black line.

The registration number code has different sign for food and beverage, for example, "Madurasa" that was produced for the first time in 1984 registered using "TR" code meaning "domestic traditional medicine product". The next development in 2006 created the brand "Madurasa Superman" using "SD" code meaning "domestic supplementary product". In 2009, all of Madurasa products or brands, in addition to bottle packaging, were reregistered using "MD" code meaning "domestic food/beverage product". Up to now, most "Madurasa" brands are encoded with "MD" with the exception of "Madurasa Murni" brand, "Madurasa Klengkeng", "Madurasa Premium", the honey content of which is richer, are approached with "jamu (herb)" with "TR" code. To get such the code number, PT. Air Mancur should comply with the criteria and the procedure of food product assessment from BPOM RI. The chapter II of its rule states that "the criteria of food product on the label or packaging should be true and not misguiding, in relation to either writing or figure or any other shape, by including the product name, net weight or net content, and the name and address of producer.

BPOM RI also takes the brand name into account, like the "Madurasa Special" name created in 2000. In 2010, the brand name was renamed into "Madurasa Premium". The word "special" becomes a concern for the BPOM RI. What makes "Madurasa" special while the main material is also honey just as same as other product. The technical manual of Traditional Medicine Advertisement Guidelines states that traditional medicine (jamu) advertisement may not use the words: "super", "ultra", "estimewa", "top", "tokcer", "cespleng", "manjur", and other words having similar meaning expressing the efficacy and excessive benefit or promising that the traditional medicine (jати) can cure definitely. Through this regulation, the word "special" was changed into "premium".

\section{b) Advertising Etiquette and Ethical Code}

In the general application of Indonesian advertising etiquette and procedure, it is mentioned that "advertisement may not be misguiding, by giving incorrect information, deceiving and giving excessive promise". Considering such the stipulation, the advertisement should be honest and frank corresponding to the quality of advertised product; there should be a healthy competition among the competitor, and advertisement should be based on the healthy competition principle.

The Health Minister's decree number 386/MEN.KES/SK/IV/1994 about beverage advertising guidelines states that the advertisement of beverage made of certain natural material may be advertised as natural material only. "Madurasa Klengkeng" is the honey product deriving from klengkeng fruit flower essence, with content density more than $10 \%$. Such the honey is mainly made of natural main material, therefore the packaging may feature photography technique displaying natural material, because it is entirely made of natural material.

It is different from the design of "Madurasa Stick" packaging created on January $24^{\text {th }}, 2007$ in the form of grape, orange, and strawberry fruits picture using photography becoming the problem. Such the pictures seem to be really made of fresh fruit and tempting everyone to drink it. The packaging was redesigned on July $9^{\text {th }}$, 2008 to remove the figure of fruit, and to replace it with purple, green and red hexagon organized tidily. Such the change of figure was conducted based on BPOM RI's recommendation because such the product contains no more than $10 \%$ fruit or contain less fruit.

In the special application of Indonesian advertising etiquette and procedure, it is mentioned that "health, passion, and beauty" will be obtained by drinking vitamin and mineral only. For that reason, "Madurasa" was reprimanded by BPOM RI because of the slogan "sehat setiap hari (being healthy everyday)" in Madurasa product packaging in 1998. With this slogan, "Madurasa" was considered as giving health everyday to those consuming it. Therefore, in 2008, the slogan was changed into "minuman dengan madu (beverage with honey)", because "Madurasa" branded- honey product had expanded into beverage product. 


\section{c) Intellectual property right}

Intellectual property right is the one arising for the output of brain processing producing a product or process beneficial to human being. The right to enjoy economically a product of intellectual creativity. Firmansyah (2008) states that intellectual property right in advertising media is divided into two: copyright and patent.

\section{(1) Copyright}

Sardjono (2008) states that a copyright is an exclusive right to the creator or beneficiary to pronounce or to reproduce his/her creation or to permit it. The Law No.19 of 2002 about copyright states that (1) creator is an individual or some individuals jointly produce a product on their own inspiration based on their thought, imagination, adeptness, skill, or expert poured onto the typical personal form. (2) Creation is the product of creator's creation showing its originality in science, art, or letter field. The creation is protected, like book, computer program, advertisement, published scientific work, and other scientific works.

PT. Air Mancur had ever neglected the copyright law about the design of "Madurasa" product packaging unregistering it in the Republic of Indonesia's Law and Human Right Ministry Service. Such the condition gave its competitor, "Madu Ratu" brand of Ratu Tawon Semarang traditional medicine company and "Madu Rasa Plus" of Tresno Joyo Surakarta, the opportunity by registering their sachet packaging design first. Observed more closely, both brands have similar type, color, typography and layout to that of "Madurasa" packaging design. It is the breach of copyright, as written in the Law No.19 of 2002 that taking a substantial and typical part becoming the characteristics of creation, although it is less than $10 \%$.

Although the design created by PT. Air Mancur had not been legalized as a copyright, its intellectual creativity should be appreciated. Therefore, the replication is an ethical breaking. Sardjono (2008) states that although idea replication cannot be said as breaking the copyright, but from moral aspect, those who take other ideas should be questioner for their integrity and there will be a conflict with the moral right of prior creator. In this case, PT. Air Mancur found difficulty in taking this matter to the court, because those two competitor's brands had been legalized. PT. Air Mancur was lagged behind in the term of Intellectual Property Right legality, so that it could not do much in settling this problem. PT. Air Mancur only relied on in-house advertiser to make propaganda within the public about their "Madurasa" product or brand compared with the competitors'.

\section{(2) Patent}

Patent is an exclusive right given by the State to inventor for his/her invention in technological area, for conducting his/her invention by him/herself in certain period of time or for approving other party to conduct it. Sardjono (2008) states, that patent right is given for 20 year-period since it has been received and it cannot be extended. A simple patent right is given in 10 -year period.

The presence of patent right enabled PT. Air Mancur to cooperate with American Detective Comics (DC) in creating "Maduras Superman". For this cooperation, PT. Air Mancur always featured comic figure, Superman, in a variety of "Madurasa" advertisement media, in 2007. In the agreement, PT. Air Mancur, in addition to paying royalty, should also included "DC" company logo in its advertisement media. The presence of Superman figure in "Madurasa" attracted the potential consumers' attention, particularly the children's. The cooperation ended in 2010, meaning that "Madurasa Superman" was no longer produced, with the reason of too much royalty it should pay. In author's opinion, "Madurasa Superman" was no longer produced because it was not sold out in the market, for the consumer bought not based on the quality of product, but on their interestedness in Superman figure. In addition, the secondary brand name "Superman" was only visual brand, no verbal written brand "Madurasa Superman" and no brand leading to the material of product. It made the potential consumers buying the product type or brand name hesitantly.

\section{2) Ethical Code Breach in Advertisement Media Design}

In-house advertiser, as the creator of advertising media, is always required by the company to make the advertised product sold-out. For that reason, advertiser should persuade the audience by means of creating the advertising media design. For the product or brand to be known by the public, sometimes the advertising media created pertain to the prevailing etiquette and ethical code. They break the existing rule or legislation, because of too high dramatization of "Madurasa" product's or brand's advantage. They masked the product's or brand's disadvantage by exaggerating its advantage regardless the breach, just like occurring in several "Madurasa" advertising media.

A tension had ever occurred between PT. Air Mancur and the competitors whose product, brand and packaging are similar. Observed from the design, the packaging of two honey products has similarity in typography, figure, color, and layout. This similarity occurred because the competitors imitated the PT Air Mancur's "Madurasa" packaging. In Indonesian Advertising Etiquette and Procedure, it is mentioned firmly that packaging or advertisement may not imitate other advertisement in such a way that generates an image that can 
make the consumers confused or misguide them (Indonesian Advertising Commission, 1999). In this case, PT. Air Mancur suffered from loss because there were other products joining the Madurasa's fame. Their designs are similar, what different is only the code of "Madurasa" product, "MD" (domestic beverage product), but "Honey" product "TR" (domestic traditional medicine). The comparative communication media appearance actually breaches the ethical code in which the advertisement should be based on the health prejudice principle. For that reason, in-house advertiser created brochure for "Madurasa sachet of orange variant" in 2009 comparing "Madurasa" to other competitor's 'honey' products. The media was published when "Madurasa" was imitated by the competitor, PT. Tresno Joyo Solo. The media on A4 size delivered a message with comparative communicating approach, comparing two similar product packaging between "Madurasa" of PT. Air Mancur in the left, and "Madu (Honey)" of PT. Tresno Joyo Solo in the right. The advertisement was not justified to compare directly one product to another intended to underestimate other party (Indonesian Advertising Commission, 1996).

The primary packaging "Madurasa Green Tea", "Madurasa Lemon Tea", designed on November $8^{\text {th }}$, 2011 used the bee nest with photography as the background. The picture is seems to be natural, because the bee nest contains pure honey. If it is attributed with the product existing in the packaging, there is a deviation because the product contains tea and orange more than honey. In the Technical Manual of Food-Beverage Advertising Guidelines from the Health Minister's Decree, it is mentioned that the beverage advertisement should states correct and non-misguiding information. Such the decree is the same as the Consumer Protection Law, stating that the businessmen are prohibited from offering, making advertisement of, advertising a product incorrectly.

The company profile of PT. Air Mancur in 2013 featured the figure of several paramedics wearing their uniform and attribute. They wear that attribute and carried out some activities in the laboratory of PT. Air Mancur to produce "Madurasa". This scene was not allowed to be featured in "Madurasa" advertising media. In the particular application of Food-Beverage Advertising Guidelines, it is confirmed that physicians, pharmacy experts, paramedics, and other medical personnel or their professional attribute may not be worn to advertise medicines or food-beverage.

The persuasion of advertisement is also carried out using metaphoric verbal language. The advertiser also uses metaphoric language in the product through headline, sub headline, body copy, and tagline in order to deliver its message to the audience. The words or sentences exaggerating the product, just like what PT. Air Mancur uses, can break the existing ethical code or rule. The headline in Ramadan 2006 brochure read "hidup sehat... dengan madu (living healthily ... with honey". This headline as if confirms that "Madurasa" makes body always healthy. If the headline led to health, it breaks the stipulation of Indonesian Advertising Etiquette and Procedure that the advertisement may not state that health, passion can be acquired by means of this product. Sub headline in "Madurasa Stick" poster created on August 25", 2011 read "jajanan sekolah penuh manfaat, minum setiap saat, bikin sehat dan kuat (the school snack replete with benefit, drinking it any time will make body healthy and strong)". It also breaks the "particular application" of Food-Beverage advertising Guidelines that the advertisement may not state/suggest that "this product" is always needed to complement the food the nutrition of which has been complete.

"Madurasa" leaflet created on December $16^{\text {th }}$ had body copy reading "Madurasa cepat menggantikan energi dan stamina yang terkuras sehingga vitalitas tetap terjaga (Madurasa replaces the exhausted energy and stamina thereby keeps the vitality)". Observed more closely, the body copy contains the words breaking the Advertising Ethical Code, Etiquette and Procedure: "menjamin (guarantees)", "bikin sehat (make healthy), and "menggantikan energi (replaces energy)". "Madurasa" as if can guarantee, make healthy, and replace the exhausted energy everyday. "Madurasa" makes the body remaining to be healthy for those consuming it.

Tagline in the back cover of Ramadhan 2006 brochure reads "ganti gula anda dengan madu ... agar hidup lebih sehat (substitute honey for your sugar ... for your living to be healthier). It suggest that "Madurasa" as if can substitute sugar for those with high cholesterol. "Madurasa Superman" sticker on February $13^{\text {th }}$ featured tagline "meningkatkan nafsu makan, daya tahan tubuh dan stamina (improving appetite, body immunity and stamina". It suggests that "Madurasa" seems to have extraordinary quality. Such the tagline actually breaks the Advertising Ethical Code, Etiquette and Procedure that advertisement may not state or suggest its necessity to perfect the food nutrition and for body health.

With such these breaches, PT. Air Mancur or its advertiser should be punished, because they make violation in delivering the message in advertising media. The punishment can be: (1) warning for the violation to those who violate, and related association, (2) instruction of withdrawing/ceasing; to those who violate, and related association, and the corresponding media, (3) punishment recommendation; to those who violate, and related association, and corresponding media, and Press Council and or the related Governmental institution (Indonesian Advertisement Commission, 1996). If there is a violation in certain product packaging media, it will affect the advertised product. The Food and Drug Administration's decree No: Hk.00/05.1.2569, about the Criteria and Management of Food Product Assessment, in Chapter XII, Section 25 states that "When a food 
product advertising and distribution is not consistent with BPOM RI's stipulation, it will be imposed with the following sanctions: (1) written warning, (2) temporarily ceasing of activity, (3) freezing and/or cancellation of food product registration approval, (4) withdrawal of food product from circulation. For those who break the copyright, the stipulation of Intellectual Property Right states that everyone who deliberately broadcasts, exhibits, circulates or sells to the public a creation or product resulting from a copyright or related right breaking will be sentenced with five year-imprisonment or fine of IDR 500,000,000,--

Despite rule and legislation existence, some people still break it, so that deception occurs because advertisement is a very complicated thing. Lee and Johnson (1999) states that advertisement is a dynamic public forum where the business interests, creativity, consumer need, and governmental regulation encounter. Advertising is affected by economic, social, and technological powers. Deception is not the only ethical issue the advertiser faces. If it occurs, the consumer should be able to sort and to select the product required, despite the abundant advertising media offering the apparently good products. For that reason, the consumer should be critical in consuming, by prioritizing "the need" rather than merely "desire".

\section{Discussion}

Many people argue that being creative is an original new design work that has never existed before. Madjadikara (2004) states that the creative strategy is basically an attempt or a way of selling. The creative concept should be relevant to its product, should make people understand what the advertisement message intends. It requires the advertisement media design to be oriented to target audience, therefore in-house advertiser should create it design very cautiously. For the design it creates to arrive at the audience, the organization of design elements leads to formal balance that is visible and readable, so that the potential consumers will be able to understand and then follow it up. Based on the target audience, the advertisement media design is created using a rational approach, corresponding to the condition of product. It only thinks of how to make the advertising media it created can sell the advertised product.

Ogilvy (1987) states that the good advertisement media is the one approved by the customers and selling the product without attracting the attention to itself. Such the argument is similar to in-house advertiser's perspective, stating that being creative is the advertising media created that can be acceptable to the audience and get response of purchasing action. There are two creativities in creating advertising media: the one related to the work functioned for the competition and the one related to market, how the advertisement product or brand can be sold out in the market. The advertisement media created by in-house advertiser belong to the creative one, because "Madurasa" product or brand could be known by the public. It can be seen from many variant products and secondary brands emerging.

The advertiser advertised the product or brand too enthusiastically through the advertising media it created. They had principle about how to make the product or brand acceptable to the public, so that persuasive breakthroughs were needed, one of which was by exaggerating "Madurasa". The figure of people working wearing medical uniform actually prohibited, the presence of tagline "hidup sehat... dengan madu (living healthily ...with honey" as if confirming that "Madurasa" makes body always healthy, the presence of "comparative leaflet" between "Madurasa" and the competitor's product, actually not done by PT. Air Mancur, because the advertisement should be based on the healthy prejudice.

In the presence of such the ethical code breaking, the Republic of Indonesia's Food and Drug Administration (BPOM RI) intervened to monitor the "Madurasa" development from variant product to secondary brand. BPOM is the agency issuing license for the presence of a product/brand, and monitoring the circulation of product or brand within the society. The legality of a product/a brand's circulation should be based on the BPOM RI's license, so that the product packaging includes the license number from the agency. This agency also serves as the overseer for the product or brand when there is violation against the prevailing rule. For example, "Madurasa Stick" with fruit figure should be replaced with the one with hexagon figure, because it breaks the rule that the product with pure fruit content less than $10 \%$ is not allowed to feature the figure with photography technique. Similarly, "Madurasa Murni" in bottle with the figure of sunflower on which a bee perches was replaced with the figure of honey and stirrer in 2011. This replacement was conducted because incompatibility between the figure and the product contained in the packaging. "Madurasa Murni" is the combined silk-cotton tree honey, kelengkeng honey, and forest honey, not sunflower honey.

\section{Conclusion}

In house advertising should pay attention to ethical code, creativity and target market in creating its advertising media. Some rules should be complied with and undertaken, like Press and Journalistic Law, Advertising Etiquette and Ethical Code, Consumer Law, and Intellectual Property Right (HaKI). While there so many rules the advertiser should comply with, it should sell the "Madurasa" product or brand. Through persuasive and emotional approach in creating an advertisement media, it sometimes forgets the legal borders or the existing rules so that it breaks the ethical code. Because of such the ethical code or rule breaking, BPOM 
intervened. This BPOM sent the President of PT. Air Mancur a letter requiring the withdrawal of the newly created advertising design and the replacement of it with new design. For that reason, PT. Air Mancur was forced to redesign the advertising media considered as breaking the ethical code. To prevent this from reoccurring, the company should hire an employee serving to recheck or to restudy the advertising media to be published. Through this division, the advertising media created will not become the topic because of ethical code breaking.

\section{References}

[1]. Arsyad, Azhar. Learning Media. Jakarta: PT. Raja Grafindo Persada. 2007: 3

[2]. Bourdieu, Pierre. A Cultural Production Arena, A Cultural Sociological Study, Yogyakarta: Kreasi Wacana, $1993: 76$.

[3]. Burton, Graeme. What hidden behind Media: An Introduction to A Media Study, Yogyakarta: Jalasutra, $2008: 2,90$.

[4]. Firmansyah, Muhamad. The Procedure of Administrating Intellectual Property Right, Jakarta: Visimedia, 2008: 7

[5]. http://www.scribd.com/Kode Etik Profesi

[6]. The Chairman of BPOM RI's Decree No. HK.00/05.1.2569, about the Criteria and Procedure of Food Product Assessment.

[7]. The Chairman of BPOM RI's Decree No. HK.00/05.1.2569/2004, about the Criteria and Procedure of Food Product Assessment.

[8]. The Republic of Indonesia Health Minister's Decree, No. 368/Men.Kes/SK/IV/1994, about the Advertising Guidelines for Free Medicine, Traditional Medicine, Medical Instrument, Cosmetics, House Medical Appliance, and Food-Beverage.

[9]. Indonesian Advertising Commission. National Discussion Formulation: Advertising Swakrama, Jakarta: Indonesian Advertisment Companies Association, 1996: 7, 29.

[10]. Indonesian Advertising Commission. Accomplished Indonesian Advertising Etiquette and Procedure, Jakarta: Indonesian Advertisment Companies Association, 1999: 8.

[11]. Lee, Monle \& Carla Johnson, Main Principles of Advertising in Global Perspective, Jakarta: Prenada Media Group, 1999: 24, 40.

[12]. Madjadikara, Agus S, How the Advertising Agency Produces Advertisement, Jakarta: Gramedia Pustaka Utama, $2004:$ 66, 69.

[13]. Ogilvy, David. Advertising Personnel's Acknowledgement, Jakarta: Pustaka Tangga, 1987: 123.

[14]. Rohani, Ahmad. Educative Instructional Media. Jakarta: Rineka Cipta, 1997: 2.

[15]. Sardjono, Agus. Copyright in Graphic Design, Jakarta: Yellow Dot Publishing, 2008: 7, 24, $26,27,41$.

[16]. Tester, Keith. Media Immortality, Yogyakarta: Juxtapose, 2009: 164.

[17]. Wiryawan. The Legal Foundation of Media, Yogyakarta: Pustaka Pelajar, 2007: 134 